\title{
Perspectives on the Development of the EU Crisis Management System
}

\author{
V. Stankov
}

ABSTRACT

The article reveals the main features of the European Union crisis management system and outlines the endeavors undertaken to improve it further by introducing a more proactive approach through enhancing the response mechanism and expanding the capabilities for prevention, preparedness and resilience. The article highlights the ability of the EU crisis management to meet the challenges of the security environment and respond to different scenarios, including overseas political-military crises having a strong impact on various aspects of common security. Furthermore, the article explores the capabilities of the Union to conduct military and civilian missions and operations within the Common Security and Defence Policy (CSDP) and analyzes their specific contribution to international peace and security. The article underlines the importance of self-reliant strategic airlift as a token of strategic autonomy and a provider of flexible mobility options. It goes on to argue that matters of strategic air mobility should be addressed along with the concerns preventing the use of the EU multinational battlegroups so far. Then, the article identifies the Strategic Compass, due to be adopted in 2022, as a platform for a common strategic vision for the Union's security and defense priorities, a sound basis for consensus on future response options and a facilitator for further integration of the military component of defense into the EU crisis management system. It also maintains that increased responsibilities would impose higher requirements upon the key elements of the crisis management process. The article points to intelligence as an integrated effort supporting CSDP military and civilian missions. Finally, it suggests three main approaches to the development of the European crisis management system and concludes that the main goal should be reinforcing the role of the $\mathrm{EU}$ as one of the pillars of international peace and security.

Keywords: Conflict, Crisis, Security, System

Published Online: February 16, 2022

ISSN: $2736-5522$

DOI: 10.24018 /ejsocial.2022.2.1.212

V. Stankov

Rakovski National Defense College, Sofia, Bulgaria.

(e-mail: vassilst@ abv.bg)

\section{INTRODUCTION}

The European Union has an advanced and elaborate crisis management system, which incorporates well-established and well-organized structures, highly experienced in managing crises of various nature, as well as effective practices and procedures combined in a common regulatory framework. One of the system's essential advantages is the present ambition for its further improvement on the basis of the common vision that crisis management is an important tool for protecting the security and interests of the European Union and safeguarding the well-being of its citizens.

In this regard, concrete actions are being taken to enhance the system by empowering it with new ideas and concepts that would enable a more proactive approach, which, in turn, would require an improvement of the response mechanisms and the capabilities for prevention, preparedness and resilience. Considerable attention is paid to strategic crisis management capabilities, which is a sign of the Union's growing ambition to implement broad-ranging and far-reaching strategic policies in the area of crisis management, to be carried out in practice through an integrated approach to response operations.

Structurally and functionally, the EU Crisis Management System has always been in line with the challenges of the security environment arising from its socio-economic, military-political, information, technological, environmental, health and other dimensions. The system maintains a high level of preparedness to counter various risks and threats and applies relevant instruments to respond to a potential or emerging crisis, ranging from civil protection, disaster relief and humanitarian aid to external militarypolitical crises, which may affect the EU security and interests or endanger EU citizens and facilities abroad.

The sharp escalation of the Afghanistan crisis in the summer of 2021 posed a threat to the security of EU staff and local employees, prompting an operation of evacuation and rescue from a remote hazardous 
area engulfed in military conflict. This brought to the fore a discussion about the Union's preparedness to respond fully to contingency scenarios within remote military-political crises, which have inflicted or have the potential to inflict a multifaceted negative effect upon EU security. These crises usually generate severe political, social and humanitarian implications locally, regionally and even globally and have a lasting impact on the security environment at both strategic and operational levels. Moreover, in most cases, their duration is extended as they are fuelled by a fierce struggle for power, influence and resources. Sometimes unpredictable events can rapidly unfold to aggravate further an already complicated situation.

\section{Capabilities And Challenges Overview}

In response to such crises, the EU has a wide array of capabilities to conduct military and civilian missions and operations within the Common Security and Defence Policy (CSDP), implemented by the European External Action Service (EEAS). Currently, around 5,000 military and civilian personnel are involved in 11 civilian and 7 military missions on three continents, including security and stabilization, peacekeeping and other peacetime operations such as supporting the rule of law, preventing human trafficking and piracy, providing military training and advice, etc.

The civilian and military branches of the CSDP are integral components of the EU crisis management system and their joint effort produces the desired synergy effect in the course of anti-crisis missions and operations. Together with the growing importance of military-political factors of the security environment, the contribution of EU civilian missions to the preservation of international peace and security continues to increase. This is due to the nature of existing and emerging threats and challenges that require countering hybrid actions, threats in cyberspace, organized crime, terrorism, extremism and radicalization, disinformation campaigns and attempts to manipulate public opinion, etc. In December 2021, the Council of the EU commended the contribution of the Civilian CSDP Compact, a strategic document signed in 2018 to enhance the civilian dimension of the CSDP, and reaffirmed its commitment to further strengthening the civilian branch of the CSDP.

In parallel with the return of the forceful methods as a way to settle international disputes, recent years have witnessed adversaries increasingly relying on armed forces or paramilitary units to achieve their objectives. Therefore, a number of state and non-state actors regard the use or threat of use of armed force as instrumental in pursuing their domestic and international agendas. This requires adjusting the crisis management process towards a proactive approach, which includes establishing strong-willed and comprehensive goals and reaching them through a successful combination of non-enforcement and enforcement measures aiming to mitigate, stabilize and eventually resolve the crisis in accordance with international law.

The EU successfully employs its huge political, economic and diplomatic potential in negotiations, mediation, consultations, political, financial and economic support, as well as in applying compelling methods such as restrictive measures and sanctions against a number of countries. Military units are also deployed to conduct a variety of non-combat operations, which ensure assertive and visible presence, increase the geopolitical leverage of the European Union and contribute to its strategic autonomy.

Non-combat military operations within the CSDP are planned and implemented by the Military Planning and Conduct Capability (MPCC), established in June 2017 as a permanent operational headquarters at the military strategic level within the European Union Military Staff. In November 2018, the Council of the EU made a decision on commissioning the MPCC to maintain readiness for planning and conduct of one executive operation with the participation of an EU battlegroup. Thus its permanent staff capacity will be strengthened in accordance with these new responsibilities. In the context of the EU integrated approach to crisis response, the MPCC interacts with the Civilian Planning and Conduct Capability (CPCC) - a similar structure that is subordinate to the CSDP and Crisis Response Managing Directorate, entrusted with the planning and conduct of civilian operations.

Capabilities to independently carry out essential operations within the crisis management process is a token of strategic autonomy, as well as an opportunity to better implement the core principles of crisis management - unified and centralized command and control over the response force, institutional division of responsibilities, adaptability and resilience to emerging risks and threats.

\section{A WAY FORWARD}

The events in Afghanistan from the summer of 2021 once again emphasized the importance of a selfreliant strategic airlift capability, which might be acquired through the Strategic Air Transport for Outsized Cargo (SATOC) project developed within the Permanent Structured Cooperation (PESCO). Currently, project requirements are being collected and harmonized until 2023, and a possible agreement 
on a common solution and a follow-on project is expected in 2026 (Jennings, 2021). Meanwhile, this crucial capacity is enabled through the Strategic Airlift International Solution (SALIS) and the Strategic Airlift Capability (SAC), both of which are NATO-operated initiatives providing pooled leasing of contract airlift to European NATO nations. The last SALIS contract was signed in September 2021 to cover a five-year period until 2026 (Heimging, 2021).

Readily available strategic airlift provides the response assets, military and civilian alike, with flexible mobility options, necessary to respond promptly to a wide variety of situations across a broad geographical area. It increases significantly the scope of the anti-crisis operations like rapid deployment of the reaction force, rescue and evacuation, air logistics, supply of humanitarian aid, etc.

In order for air mobility to fully contribute to CSDP operations, it would be relevant to address the problem of strategic airlift in combination with the use of EU multinational battlegroups which, for various reasons, have not been so far involved in operations, although they have been ready for action since 2007. The EU battlegroups are usually combined arms battalion sized (about 1500 personnel strong), reinforced with combat and combat service support. On a rotational basis, two battlegroups are always on standby for a period of 6 months (Vincent, 2018). Activation of battlegroups to counter crises and conflicts has been hampered so far by the lack of unanimous consent within the EU on problems related to the military-strategic context of battlegroup deployment, operational command and control and financing.

Moreover, air mobility shall attribute an expeditionary quality to the military response forces enabling them to maintain high operational readiness to carry out missions in accordance with their main tasks and objectives - conflict prevention, initial stabilization, humanitarian interventions and rescue, crisis management, peacekeeping.

The "Strategic Compass" document, due to be adopted in 2022, could serve as a basis for a lasting strategic consensus on future response options. It will set out a common and unified approach to the crisis management process and will further integrate the military component of defense into the EU crisis management system. More importantly, the Strategic Compass is expected to build a unified strategic vision for the Union's security and defense priorities. This is going to be achieved through identifying present-day and forthcoming global and regional threats, including specific threats against Union security, and highlighting probable crisis management scenarios related to the future military and civilian missions. The common understanding and awareness of existing and unfolding security threats will consolidate the EU efforts aimed at improving the preparedness of the military and civilian branches of European defense and will expand the opportunities for joint investment in key military capabilities consisting of land, sea and air components and military space and cyber security assets. The level of ambition is to establish a Rapid Deployment Capacity of 5,000 troops enabled to conduct strategic-level operations.

Increased responsibilities will entail higher requirements to the key elements of the crisis management system. Firstly, the role of monitoring will significantly increase, which includes continuous observation of possible crisis events in the security environment by gathering information from multiple sources. Processing and analysis of the information collected will be vitally important for the system's capacity to properly and promptly identify potential crises, set up early warning of emerging crises and forecast the development of existing crises. Accurate strategic assessments will be at the heart of crucial and responsible decisions that will leave a lasting imprint on the security environment and will have a tangible impact on the security of the European Union and its citizens.

Secondly, crisis and conflict prevention and related structured activities, such as the Conflict Analysis done by the EEAS Conflict Prevention Team and the EU conflict Early Warning System, both implemented by the Conflict Prevention and Mediation Support Division within the Integrated Approach for Security and Peace Directorate of the EEAS, will become increasingly important.

Last but not least, all this will further enhance the role of intelligence conducted as an integrated effort supporting CSDP military and civilian missions and implemented as a crucial tool for situational awareness, early warning, strategic analysis, decision-making and operational planning. Interaction and coordination between the EU Military Staff Intelligence Directorate (EUMS INT) and the EU Intelligence and Situation Center (EU INTCEN) will inevitably intensify, including within the Single Intelligence Analysis Capacity (SIAC), while they both will cooperate closely with the European Union Satellite Center (SatCen). Since its establishment in 2007, SIAC enhances civil/military intelligence to support anticipation and situational awareness and to provide strategic information, early warning and comprehensive analysis (Seyfried, 2017).

Basically, EU crisis management can be improved through three main approaches:

1) Structural, involving refining the organizational structure of the system and its sub-systems.

2) Functional, aimed at enhancing crisis management by improving the activities done at the different stages of the process - monitoring and control of crisis phenomena, information gathering and analysis, decision-making, response forces generation and preparedness, operational planning, operational coordination, command and control, strategic communication. 
3) Combined approach, which incorporates activities referring to the first two approaches.

Any of them is applicable as long as it reaffirms and strengthens the purpose of the crisis management system as a mechanism to reinforce the role of the EU as one of the pillars of international peace and security.

\section{FUNDING}

No financial support was received for the publication of this work.

\section{REFERENCES}

EEAS homepage (2021, March 12). Security, Defence \& Crisis Response. Conflict Prevention, Peace building and Mediation. https://eeas.europa.eu/topics/security-defence-crisis-response_en

Euronews \& AP (2021, Sep 2). Afghanistan crisis sparks debate over EU's military capabilities. https://www.euronews.com/2021/09/01/europe-failed-on-kabul-airlift-afghanistan-refugees-eu-officials

Hages, L. (2014). Europe's Strategic Airlift Gap, Quantifying the Capability Gap and Measuring Solutions. JAPCC Journal, 19, https://www.japcc.org/europes-strategic-airlift-gap/

Heimging, G. (2021). SALIS Contract Extended for Five Years. European Security and Defense, https:/leurosd.com/2021/11/articles/exclusive/24601/salis/

Jennings, G. (2021). EU launches new strategic airlifter effort https. JANES, https://www.janes.com/defence-news/news-detail/eulaunches-new-strategic-airlifter-effort

Seyfried, P. (2017). A European Intelligence Service? Potentials and Limits of Intelligence Cooperation at EU Level. Federal Academy for Security Policy, Security Policy Working Paper No. 20/2017, https://www.baks.bund.de/sites/baks010/files/working_paper_2017_20.pdf

Vincent, M. (2018). EU Battlegroups: The European' army' that politicians can't agree how to use. ABC News, https://www.abc.net.au/news/2018-11-17/the-european-army-that-has-never-been-in-a-fight/10506466

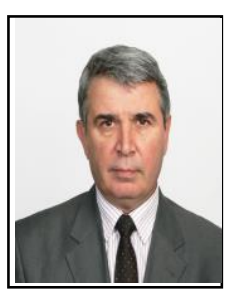

Vasil Stankov was born in Bulgaria on 9 January 1964. He holds a Master's degree in Military Studies from Georgi Benkovski Air Force Academy in Bulgaria completed in 1887 and a PhD degree in Military-Political Problems of Security from Rakovski National Defense College in Sofia, Bulgaria, 2015. Major fields of study are defense and security, crisis and conflict management, geopolitics.

He has served in various positions in the Bulgarian Armed Forces and is currently an Associate Professor in Rakovski National Defense College in Sofia, Bulgaria.

Assoc. Prof. Stankov has two monographs and a number of scientific articles and research reports in Bulgarian. His publications in English are:

- Stankov, V. (2019). The Role of the European Union for the Settlement of the Conflict in Syria. Socioint, 6th International Conference on Education, Social Sciences and Humanities, 24-26 June, 2019-Istanbul, p. 511-514. ISBN: 978-605-82433-6-1. http://www.ocerints.org/socioint19_e-publication/abstracts/a287.htm.

- Stankov, V. (2019). International Peace Initiatives to Resolve the Conflict in Syria. Socioint, 6th International Conference on Edication, Social Sciences and Humanities, 24-26 June, 2019-Istanbul, p. 493-498. ISBN: 978-605-82433-6-1. http://www.ocerints.org/socioint19_e-publication/abstracts/papers/275.pdf

- Stankov, V. (2019). Iranian Involvement in the Syrian Conflict. KNOWLEDGE -International Journal Vol.30.6. March, 2019 , p. 1437-1440. ISSN 1857-923X (for e-version). ISSN 2545 - 4439 (for printed version). https://ikm.mk/ojs/index.php/KIJ/article/view/949/381 